\title{
GENETIC DIVERSITY OF MYCOBACTERIUM AVIUM sUbSP. HOMINISSUIS STRAINS ISOLATED IN ITALY BASED ON VNTR LOCI ANALYSIS
}

\author{
M. Menichini, F. Genua, N. Lari, L. Rindi \\ Università di Pisa, Pisa, Italy
}

\begin{abstract}
Background. Mycobacterium avium subsp. hominissuis (MAH) is an important pathogen responsible for most of the human-associated nontuberculous mycobacteria infections. Over the past few decades the incidence of MAH infections is increasing in Italy, as in many countries worldwide. The present study is aimed to elucidate the genetic characteristics of MAH strains isolated from human patients using VNTR typing and to show the genetic relatedness among them. Methods. The genetic diversity of 108 human isolates of MAH was determined by VNTR analysis targeting 8 loci, coded 32, 292, X3, 25, 3, 7, 10 and 47. Results. The VNTR analysis revealed 25 distinct VNTR patterns; of these, 13 patterns were unique, while 12 patterns were shared by 2 or more isolates, thus yielding 12 clusters including a total of 95 isolates. The discriminatory power of our VNTR analysis yielded an HGDI of 0.990 , indicating that VNTR typing has an excellent discriminatory power. No association of a particular VNTR pattern with a particular clinical feature, such as the disseminated, pulmonary or extrapulmonary type of infection, was observed. Minimum spanning tree analysis showed that 21 VNTR patterns, occurring either as clustered or unique isolates, differed from the nearest one for one allelic variation. Conclusions. The results obtained through the VNTR analysis showed that most MAH strains displayed a close genetic relationship. This high phylogenetic proximity of the VNTR loci over a long time period supports the concept that the MAH genotype is highly homogeneous in our geographical area, suggesting the hypothesis of the presence of possible sources of infection and transmission pathways at the local level.
\end{abstract}

Key words: Mycobacterium avium, population structure, Italy, VNTR loci, mycobacteriosis.

\section{ГЕНЕТИЧЕСКОЕ РАЗНООБРАЗИЕ ШТАММОВ MYСОВАСТЕRIUM AVIUM sUbSP. HOMINISSUIS, ВЫДЕЛЕННЫХ В ИТАЛИИ, НА ОСНОВЕ АНАЛИЗА ЛОКУСОВ VNTR}

Меникини М., Дженуа Ф., Лари Н., Ринди Л.

Университет Пизы, г. Пиза, Италия

Резюме. Mycobacterium avium subsp. hominissuis является наиболее актуальным возбудителем микобактериоза человека. За последние несколько десятилетий в Италии заболеваемость микобактериозом M. avium subsp. hominissuis растет, как и во многих странах мира. Целью исследования была молекулярно-генетическая характеристика и оценка генетического родства штаммов M. avium subsp. hominissuis, выделенных от больных микобактериозом в Италии, с использованием VNTR (variable number of tandem repeats)-типирования. Аллельный полиморфизм 108 штаммов M. avium subsp. hominissuis оценивали методом VNTR-типирования по 8 локусам - 32, 292, X3, 25, 3, 7, 10 и 47. С помощью VNTR-типирования было выявлено 25 вариантов VNTRтипов; из них 13 профилей были уникальными, а 12 профилей представлены кластерами (включающими

\author{
Адрес для переписки: \\ Лаура Ринди \\ Виа Сан Зено, 35/39, 56127 Пиза, Италия, \\ Отдел трансляционных исследований и новых технологий \\ в медицине и хирургии Университета Пизы. \\ Тел.: +39050 2213688. Факс: +390502213682. \\ E-mail: laura.rindi@med.unipi.it
}

Библиографическое описание:

Меникини М., Дженуа Ф., Лари Н., Ринди Л. Генетическое разнообразие штаммов Mycobacterium avium subsp. hominissuis, выделенных в Италии, на основе анализа локусов VNTR // Инфекция и иммунитет. 2018. T. 8, № 4. C. 441-446. doi: 10.15789/2220-7619-2018-4-441-446

\author{
Contacts: \\ Laura Rindi \\ Via San Zeno, 35/39, 56127 Pisa, Italy, \\ Dipartimento di Ricerca Traslazionale e delle Nuove Tecnologie \\ in Medicina e Chirurgia. \\ Phone: +39050 2213688. Fax: +390502213682. \\ E-mail: laura.rindi@med.unipi.it
}

\section{Citation:}

Menichini M., Genua F., Lari N., Rindi L. Genetic diversity of Mycobacterium avium subsp. hominissuis strains isolated in Italy based on vntr loci analysis // Russian Journal of Infection and Immunity = Infektsiya i immunitet, 2018, vol. 8, no. 4, pp. 441-446. doi: 10.15789/2220-7619-2018-4-441-446 
2 и более изолятов), в состав которых входило 95 изолятов. Дискриминирующая способность VNTRтипирования (индекс Хантера-Гастона, Hunter Gaston discriminatory index) составила 0.990, что указывает на высокую дискриминирующую способность использованной схемы VNTR. Связи между профилем VNTR и клинической формой микобактериоза (генерализованная, легочная или внелегочная) не обнаружено. Анализ минимального связывающего дерева профилей VNTR показал, что 21 VNTR-тип (как уникальные изоляты, так и кластеры двух и более изолятов) входили в единый клональный комплекс в котором соседние узлы различались по одному локусу. Полученные результаты VNTR-типирования выявили близкое родство изученных штаммов M. avium subsp. hominissuis. Высокий уровень филогенетического родства по локусам VNTR для штаммов, выделенных в течение длительного периода, подтверждает концепцию о том, что M. avium subsp. hominissuis очень гомогенен в нашей географической области в Италии, что, в свою очередь, подкрепляет гипотезу о наличии возможных источников инфекции и путей ее передачи на местном уровне.

Ключевые слова: Mycobacterium avium, структура популяции, Италия, локусы VNTR, микобактериоз.

\section{Introduction}

In many countries worldwide the incidence of nontuberculous mycobacteria (NTM) infections is increasing over the past few decades [11]. Mycobacterium avium complex is responsible for most of the humanassociated nontuberculous mycobacteria infections [1]. Mycobacterium avium, one of the members of the M. avium complex, includes 4 subspecies, each endowed with specific pathogenetic and host range characteristics: M. avium subsp. paratuberculosis, that causes the Johne's disease in ruminants; M. avium subsp. avium, that infects birds; M. avium subsp. silvaticum, that infects wood pigeons; and M. avium subsp. hominissuis (MAH), that is usually isolated from human and swine sources [14, 20]. MAH is an important pathogen that causes not only disseminated diseases in patients with human immunodeficiency virus infection but also pulmonary disease, even in immunocompetent patients [19], and the incidence of pulmonary MAH infection is increasing in Italy [14].

Control of MAH infections in humans requires knowledge of its epidemiology and biodiversity of the strains. The variable numbers of tandem repeats (VNTR) analysis is a genotyping method that has been proven to be a rapid and reliable method with a high discriminatory power for MAH isolates [5, 17]. The present study is aimed to elucidate the genetic characteristics of MAH strains isolated from human patients using VNTR typing and to show the genetic relatedness among them.

\section{Materials and Methods}

Clinical isolates. A set of $108 \mathrm{MAH}$ strains, identified by InnoLipa probes and by a multiplex PCR designed to discriminate MAC organisms [16], isolated from 1990 to 2016 in the Laboratory of Clinical Mycobacteriology of the University Hospital of Pisa, Italy, from the same number of patients, were studied. Fifty isolates were from respiratory specimens, 19 from blood, 15 from lymph nodes, 7 from specimens other than respiratory specimens, blood and lymph nodes, and 17 from an unknown source.
VNTR analysis. Genomic DNA was extracted by the cetyltrimethyl-ammonium bromide (CTAB) method. VNTR typing was performed by PCR using specific primers for the eight loci identified as polymorphic for $M$. avium subsp. paratuberculosis K10 and coded 32, 292, X3, 25, 3, 7, 10 and 47, as described previously [17]. The PCR fragments were analyzed by gel electrophoresis using 2\% NuSieve agarose (Cambrex Bio Science Rockland). For each locus, sizes of amplicons were estimated by comparison with $20 \mathrm{bp}$ and $100 \mathrm{bp}$ markers (Superladder-low; GenSura, CA, USA) and the numbers of repetitive units were determined according with a previously described allele-calling table [17]. VNTR profile is expressed as a string of 8 numbers, each representing the number of tandem repeats (TR) at a given VNTR position, in the order given above. The allelic diversity $(h)$ of the VNTR loci was calculated using the equation $h=1-\sum x_{\mathrm{i}}^{2}\{\mathrm{n} /(\mathrm{n}-1)\}$ where $\mathrm{n}$ is the number of isolates and $x_{i}$ the frequency of the $i^{\text {th }}$ allele at the locus (Selander et al., 1986). The global discriminatory power of complete VNTR scheme (HGDI) was determined using the Hunter and Gaston discriminatory index (HGDI) [2]. The HGDI was calculated using the following formula:

$$
D=1-\frac{1}{N(N-1)} \sum_{J=1}^{s} x j(x j-1),
$$

where $N$ is the total number of isolates in the typing scheme, $s$ is the total number of distinct subtypes discriminated by the typing method, and $x j$ is the number of isolates belonging to the $x^{\text {th }}$ subtype.

Genetic relationships analysis. VNTR data were analyzed by the MIRU-VNTRplus web application available at www.miru-vntrplus.org; VNTR profile similarities were visualized by generating a dendrogram using the unweighted pair group method with arithmetic averages (UPGMA); the genetic relationships among the isolates were analyzed by constructing a minimum spanning tree (MST), an undirected network in which all the VNTR profiles are linked together with the smallest possible linkages between nearest neighbours, by the UPGMA method. 
Table 1. VNTR allelic distribution in $108 \mathrm{MAH}$ clinical isolates

\begin{tabular}{|c|c|c|c|c|c|c|c|c|}
\hline \multirow{2}{*}{$\begin{array}{l}\text { No. of tandem } \\
\text { repeat copies }\end{array}$} & \multicolumn{8}{|c|}{ No. of isolates at the VNTR locus } \\
\hline & 32 & 292 & X3 & 25 & 3 & 7 & 10 & 47 \\
\hline 0 & & 19 & & & & & & \\
\hline 1 & & 1 & & 1 & 108 & 108 & 1 & \\
\hline 2 & & 85 & 48 & 82 & & & 104 & 96 \\
\hline 3 & & 1 & 4 & 23 & & & & 12 \\
\hline 4 & & & 25 & 1 & & & & \\
\hline 5 & 2 & & 30 & & & & 3 & \\
\hline 6 & & & & & & & & \\
\hline 7 & 2 & & & & & & & \\
\hline 8 & 62 & & & & & & & \\
\hline 9 & 39 & & & & & & & \\
\hline 10 & 2 & & & & & & & \\
\hline $\mathrm{nd}^{*}$ & 1 & 2 & 1 & 1 & & & & \\
\hline$h^{\star \star}$ & 0.57 & 0.32 & 0.66 & 0.36 & 0 & 0 & 0.06 & 0.19 \\
\hline
\end{tabular}

* not determined (no PCR product was obtained). ** allelic diversity (h) was calculated as described by Selander et al. (1986).

\section{Results}

The genetic diversity of 108 MAH human strains, isolated over a two 25 year-period in the Laboratory of Clinical Mycobacteriology of the University Hospital of Pisa, Italy, was investigated by determining the polymorphism of a set of eight MIRU-VNTR loci as previously described by Thibault et al. [17]. We first quantified the resolution provided by each VNTR locus by calculating its allelic diversity, which depends upon both the number and the distribution of the alleles, according to Selander et al. [15]. As shown in Table 1, the allelic diversity (h) of the VNTR loci of our collection varied widely, from 0 to 0.66 . The VNTR loci 32 and X3 had a high diversity index $(h \geq 0.5)$; three loci $(292,25,47)$ showed medium diversity index $(0.1 \leq h \leq 0.5)$; the locus 10 achieved a low diversity index $(h \leq 0.1)$; the last two loci $(3,7)$ did not show any allelic diversity.

The VNTR analysis revealed 25 distinct VNTR patterns; of these, 13 patterns were unique, while 12 patterns were shared by 2 or more isolates, thus yielding 12 clusters including a total of 95 isolates. In particular, 1 cluster consisting of 24 strains, 1 cluster of 15 strains, 2 clusters of 11 strains, 1 cluster of 9 strains, 1 cluster of 7 strains, 1 cluster of 5 strains, 1 cluster of 4 strains, 1 cluster of 3 strains and finally 3 clusters of 2 strains were identified. The discriminatory power of our VNTR analysis yielded an HGDI of 0.990, indicating that VNTR typing has an excellent discriminatory power. Table 2 shows VNTR profiles and localization of infection of clustered and unique MAH strains; no association of a particular VNTR pattern with a particular clinical feature, such as the disseminated, pulmonary or extrapulmonary type of infection, was observed.

The genetic relationships between the study isolates were then visualized by constructing a minimum spanning tree (MST) based on the VNTR profiles. The MST reflects the variations from one
Table 2. Characteristics of MAH strains

\begin{tabular}{|c|c|c|c|c|c|}
\hline \multirow[b]{2}{*}{$\begin{array}{c}\text { VNTR } \\
\text { pattern }^{a}\end{array}$} & \multirow{2}{*}{ 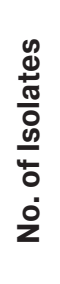 } & \multicolumn{4}{|c|}{$\begin{array}{c}\text { No. of isolates with specific } \\
\text { localization }^{\mathrm{b}}\end{array}$} \\
\hline & & 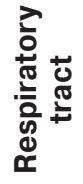 & $\frac{\overline{0}}{\frac{0}{\infty}}$ & 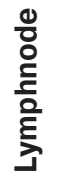 & Dे \\
\hline 82221122 & 24 & 12 & 5 & 5 & 1 \\
\hline 92221122 & 15 & 10 & - & 3 & - \\
\hline 82421122 & 11 & 2 & 6 & 1 & 1 \\
\hline 92421122 & 11 & 4 & - & - & - \\
\hline 82521122 & 9 & 3 & 1 & 3 & - \\
\hline 80531122 & 7 & 2 & 1 & - & 4 \\
\hline 80531123 & 5 & 3 & 2 & - & - \\
\hline 92521122 & 4 & 1 & 1 & 1 & - \\
\hline 90531122 & 3 & - & - & 1 & - \\
\hline 82231122 & 2 & 2 & - & - & - \\
\hline 52421122 & 2 & - & 2 & - & - \\
\hline 90221122 & 2 & 2 & - & - & - \\
\hline 82321122 & 1 & - & - & - & 1 \\
\hline 102221122 & 1 & 1 & - & - & - \\
\hline 90421122 & 1 & 1 & - & - & - \\
\hline 82231123 & 1 & 1 & - & - & - \\
\hline 82241123 & 1 & 1 & - & - & - \\
\hline 82221123 & 1 & 1 & - & - & - \\
\hline 92221113 & 1 & 1 & - & - & - \\
\hline 82531122 & 1 & - & - & 1 & - \\
\hline 100531122 & 1 & 1 & - & - & - \\
\hline 72511123 & 1 & - & 1 & - & - \\
\hline 71331152 & 1 & - & - & - & - \\
\hline 93331153 & 1 & 1 & - & - & - \\
\hline 90331153 & 1 & 1 & - & - & - \\
\hline
\end{tabular}

${ }^{a}$ VNTR patterns are expressed as strings of 8 numbers, each representing the number of tandem repeats at a given VNTR position, in the following order: locus 32, 292, X3, 25, 3, 7, 10, 47.

bocalization was unknown for 17 patients. 
allele to another due to the loss or gain of one tandem repeat sequence at a single VNTR locus. The MST, illustrated in Figure, shows that most (21 out of 25) VNTR patterns, occurring either as clustered or unique isolates, differed from the nearest one for one allelic variation; one VNTR pattern differed for 2 allelic variations; three VNTR patterns differed for 3 allelic variations. By this analysis, the 25 VNTR profiles described above yielded two clonal complexes, termed $\mathrm{CC} 1$ and $\mathrm{CC} 2$, including 21 and 2 unique profiles, respectively. CC1 (white in Fig.) included a total of 104 isolates, 95 of which clustered in the 12 clusters. CC2 (grey in Fig.), that differed from $\mathrm{CC} 1$ for three allelic variations, included 2 isolates with unique VNTR profile.

\section{Discussion}

The aim of the present study was to determine the genetic diversity of MAH strains isolated in a region of Italy by analyzing a set of eight VNTR loci. The VNTR typing assay employed in the present study showed that 5 VNTR loci of our MAH iso- lates (i.e., loci 32, 292, X3, 25 and 47) were enough polymorphic to yield an acceptable allelic diversity. Indeed, in agreement with previous reports [4, 10, 12, $17,18]$, locus VNTR X3 turn out to be the most polymorphic, while loci VNTR 3, VNTR 7 and VNTR 10 were the least suitable for VNTR typing of MAH isolates. Our VNTR analysis, that yielded 25 unique VNTR patterns and identified 12 clusters including a total 95 isolates, showed an excellent discriminatory power $(\mathrm{HGDI}=0.990)$, similar to that obtained with VNTR schemes used by other authors [4, 5]. The results obtained through the VNTR analysis showed that most MAH strains displayed a close genetic relationship, as indicated by the minimum spanning tree analysis; in fact, 21 out of 25 VNTR patterns of the MAH isolates, occurring either as clustered or unique isolates, differed from the nearest one only for one allelic variation. This high phylogenetic proximity of the VNTR loci over a long time period supports the concept that the MAH genotype is highly homogeneous in our geographical area. Other studies demonstrated geographical differences in genetic diversity of MAH, suggesting the hypo-

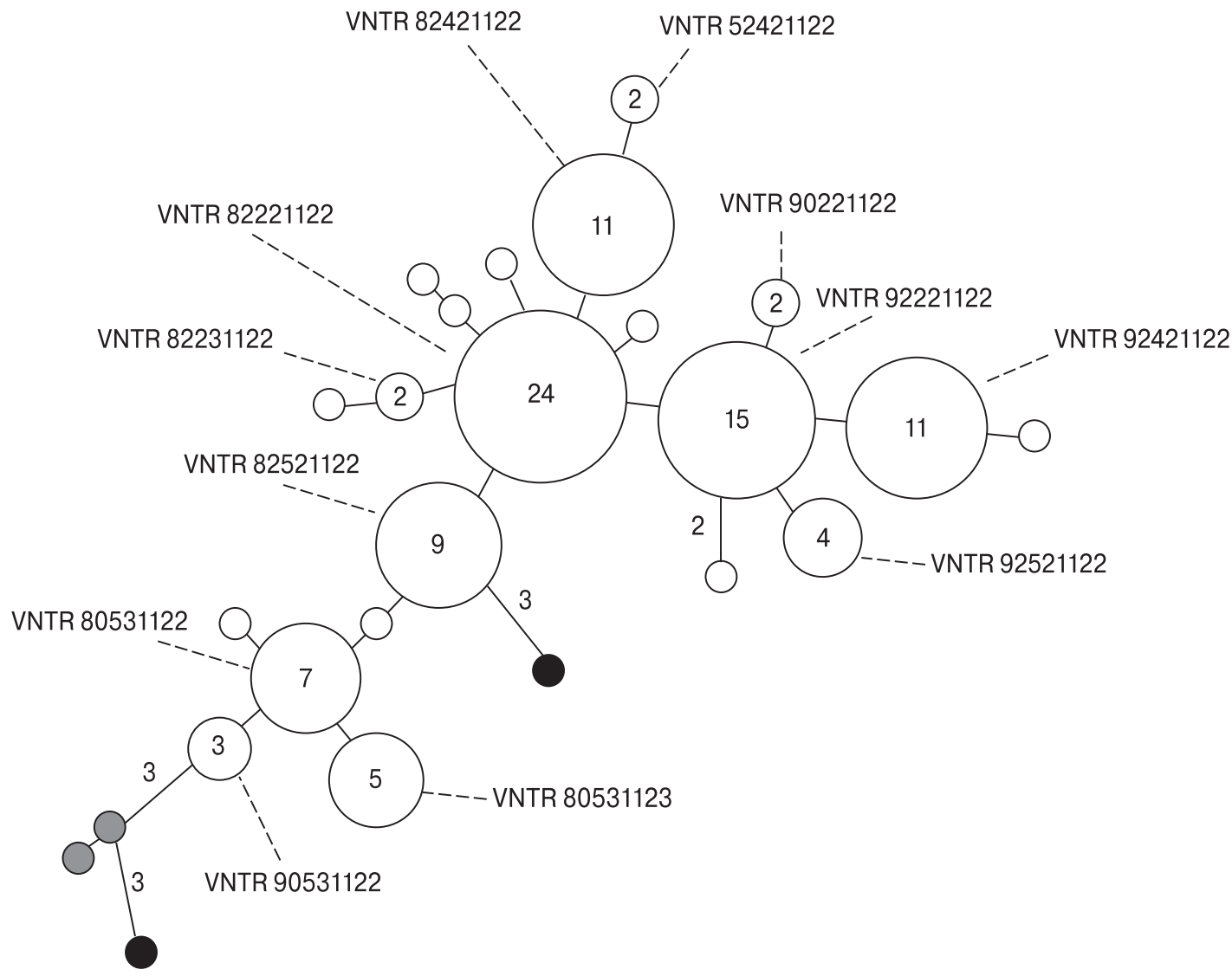

Figure. Minimum spanning tree based on VNTR profiles of a set of 8 loci of 108 MAH clinical isolates

Each small-size circle represents a single isolate; larger circles represent clusters of 2-24 isolates, depending on the circle size, with identical VNTR profiles. For each cluster the number of the isolates is given in the circle and the VNTR profile in the callouts. Numbers next to the branches indicate the level of changes more than 1 induced by loss or gain of VNTR copies at a given locus, yielding a change from one allele to another. White and grey circles indicate VNTR profiles belonging to clonal complexes CC1 and CC2, respectively, detected by the analysis at single locus variance. The tree was generated using the UPGMA method by the MIRU-VNTRplus web application available at www.miru-vntrplus.org. 
thesis of the presence of possible sources of infection and transmission pathways at the local level $[3,6,7$, $8,9]$. Interestingly on this subject, a recent population structure study postulated the emergence of human-adapted MAH lineages on local scale, and suggested that recombination facilitates local adaptation of MAH [21].

In order to achieve a better control of MAH infection, further investigations on larger collections of MAH strains of human, animal and environmental origin are needed to clarify the sources of infection, the specific transmission pathway and the local adaptation mechanisms of MAH.

\section{Acknowledgments}

This work was financially supported by the University of Pisa, grant "Fondi di Ateneo, 2016".

\section{Список литературы/References}

1. Griffith D.E., Aksamit T., Brown-Elliott B.A., Catanzaro A., Daley C., Gordin F., Holland S.M., Horsburgh R., Huitt G., Iademarco M.F., Iseman M., Olivier K., Ruoss S., von Reyn C.F., Wallace R.J. Jr, Winthrop K. An official ATS/IDSA statement: diagnosis, treatment, and prevention of nontuberculous mycobacterial diseases. Am. J. Respir. Crit. Care Med., 2007, vol. 175, pp. 367-416. doi: 10.1164/rccm.200604-571ST

2. Hunter P.R., Gaston M.A. Numerical index of the discriminatory ability of typing systems: an application of Simpson's index of diversity. J. Clin. Microbiol., 1988, vol. 26, pp. 2465-2466.

3. Ichikawa K., van Ingen J., Koh W.J., Wagner D., Salfinger M., Inagaki T., Uchiya K.I., Nakagawa T., Ogawa K., Yamada K., Yagi T. Genetic diversity of clinical Mycobacterium avium subsp. hominissuis and Mycobacterium intracellulare isolates causing pulmonary diseases recovered from different geographical regions. Infect. Genet. Evol., 2015, vol. 36, pp. 250-255. doi: 10.1016/j. meegid.2015.09.029

4. Imperiale B.R., Moyano R.D., Di Giulio A.B., Romero M.A., Alvarado Pinedo M.F., Santangelo M.P., Traveria G.E., Morbillo N.S., Romano M.I. Genetic diversity of Mycobacterium avium complex strains isolated in Argentina by MIRU-VNTR. Epidemiol. Infect., 2017, vol. 145, pp. 1382-1391. doi: 10.1017/S0950268817000139

5. Inagaki T., Nishimori K., Yagi T., Ichikawa K., Moriyama M., Nakagawa T., Shibayama T., Uchiya K., Nikai T., Ogawa K. Comparison of a variable-number tandem-repeat (VNTR) method for typing Mycobacterium avium with mycobacterial interspersed repetitive-unit-VNTR and IS1245 restriction fragment length polymorphism typing. J. Clin. Microbiol., 2009, vol. 47, pp. 2156-2164. doi: 10.1128/JCM.02373-08

6. Iwamoto T., Nakajima C., Nishiuchi Y., Kato T., Yoshida S., Nakanishi N., Tamaru A., Tamura Y., Suzuki Y., Nasu M. Genetic diversity of Mycobacterium avium subsp. hominissuis strains isolated from humans, pigs, and human living environment. Infect. Genet. Evol., 2012, vol. 12, pp. 846-852. doi: 10.1016/j.meegid.2011.06.018

7. Kalvisa A., Tsirogiannis C., Silamikelis I., Skenders G., Broka L., Zirnitis A., Jansone I., Ranka R. MIRU-VNTR genotype diversity and indications of homoplasy in M. avium strains isolated from humans and slaughter pigs in Latvia. Infect. Genet. Evol., 2016, vol. 43, pp. 15-21. doi: 10.1016/j.meegid.2016.05.013

8. Muwonge A., Oloya J., Kankya C., Nielsen S., Godfroid J., Skjerve E., Djønne B., Johansen T.B. Molecular characterization of Mycobacterium avium subspecies hominissuis isolated from humans, cattle and pigs in the Uganda cattle corridor using VNTR analysis. Infect. Genet. Evol., 2014, vol. 21, pp. 184-191. doi: 10.1016/j.meegid.2013.11.012

9. Nishiuchi Y., Iwamoto T., Maruyama F. Infection sources of a common non-tuberculous mycobacterial pathogen, Mycobacterium avium complex. Front. Med., 2017, vol. 4: 27. doi: 10.3389/fmed.2017.00027

10. Pate M., Kušar D., Zolnir-Dovč M., Ocepek M. MIRU-VNTR typing of Mycobacterium avium in animals and humans: heterogeneity of Mycobacterium avium subsp. hominissuis versus homogeneity of Mycobacterium avium subsp. avium strains. Res. Vet. Sci., 2011, vol. 91, pp. 376-381. doi: 10.1016/j.rvsc.2010.10.001

11. Prevots D.R., Marras T.K. Epidemiology of human pulmonary infection with nontuberculous mycobacteria: a review. Clin. Chest Med., 2015, vol. 36, pp. 13-34. doi: 10.1016/j.ccm.2014.10.002

12. Radomski N., Thibault V.C., Karoui C., de Cruz K., Cochard T., Gutiérrez C., Supply P., Biet F., Boschiroli M.L. Determination of genotypic diversity of Mycobacterium avium subspecies from human and animal origins by mycobacterial interspersed repetitive-unit-variable-number tandem-repeat and IS1311 restriction fragment length polymorphism typing methods. J. Clin. Microbiol., 2010, vol. 48, pp. 1026-1034. doi: 10.1128/JCM.01869-09

13. Rindi L., Garzelli C. Genetic diversity and phylogeny of Mycobacterium avium. Infect. Genet. Evol., 2014, vol. 21, pp. $375-383$. doi: 10.1016/j.meegid.2013.12.007

14. Rindi L., Garzelli C. Increase in non-tubercolous mycobacteria isolated from humans in Tuscany, Italy, from 2004 to 2014 . $B M C$ Infect. Dis., 2016, vol. 16: 44. doi: 10.1186/s12879-016-1380-y

15. Selander R.K., Caugant D.A., Ochman H., Musser J.M., Gilmour M.N., Whittam T.S. Methods of multilocus enzyme electrophoresis for bacterial population genetics and systematics. Appl. Environ. Microbiol., 1986, vol. 51, pp. 873-884.

16. Shin S.J., Lee B.S., Koh W.J., Manning E.J., Anklam K., Sreevatsan S., Lambrecht R.S., Collins M.T. Efficient differentiation of Mycobacterium avium complex species and subspecies by use of five-target multiplex PCR. J. Clin. Microbiol., 2010, vol. 48, pp. 4057-4062. doi: 10.1128/JCM.00904-10

17. Thibault V.C., Grayon M., Boschiroli M.L., Hubbans C., Overduin P., Stevenson K., Gutierrez M.C., Supply P., Biet F. New variable number tandem-repeat markers for typing Mycobacterium avium subsp. paratuberculosis and M. avium strains: comparison with IS900 and IS1245 restriction fragment length polymorphism typing. J. Clin. Microbiol., 2007, vol. 45, pp. 2404-2410. doi: 10.1128/JCM.00476-07 
18. Tirkkonen T., Pakarinen J., Rintala E., Ali-Vehmas T., Marttila H., Peltoniemi O.A., Mäkinen J. Comparison of variable-number tandem-repeat markers typing and IS1245 restriction fragment length polymorphism fingerprinting of Mycobacterium avium subsp. hominissuis from human and porcine origins. Acta Vet. Scand., 2010, vol. 52: 21. doi: 10.1186/1751-0147-52-21

19. Tortoli E. Clinical manifestation of nontuberculous mycobacteria infections. Clin. Microbiol. Infect., 2009, vol. 15, pp. $906-910$. doi: 10.1111/j.1469-0691.2009.03014.x

20. Turenne C.Y., Wallace R. Jr, Behr M.A. Mycobacterium avium in the postgenomic era. Clin. Microbiol. Rev., 2007, vol. 20, pp. 205-229. doi: 10.1128/CMR.00036-06

21. Yano H., Iwamoto T., Nishiuchi Y., Nakajima C., Starkova D.A., Mokrousov I., Narvskaya O., Yoshida S., Arikawa K., Nakanishi N., Osaki K., Nakagawa I., Ato M., Suzuki Y., Maruyama F. Population structure and local adaptation of MAC lung disease agent Mycobacterium avium subsp. hominissuis. Genome Biol. Evol., 2017, vol. 9, pp. 2403-2417. doi: 10.1093/gbe/evx183

\section{Авторы:}

Меникини М., младший научный сотрудник отдела трансляционных исследований и новых технологий в медицине и хирургии Университета Пизы, г. Пиза, Италия;

Дженуа Ф., младший научный сотрудник отдела трансляционных исследований и новых технологий в медицине и хирургии Университета Пизы, г. Пиза, Италия;

Лари Н., технический специалист отдела трансляционных исследований и новых технологий в медицине и хирургии Университета Пизы, г. Пиза, Италия;

Ринди Л., профессор отдела трансляционных исследований и новых технологий в медицине и хирургии Университета Пизы, г. Пиза, Италия.

\section{Authors:}

Menichini M., Junior Researcher, Department of Translational Research University of Pisa, Pisa, Italy;

Genua F., Junior Researcher, Department of Translational Research University of Pisa, Pisa, Italy;

Lari N., Graduate Technician, Department of Translational

Research, University of Pisa, Pisa, Italy:

Rindi L., PhD, Department of Translational Research University of Pisa, Pisa, Italy. 